\title{
Effect Of Consuming Omega 6 On Learning Achievement Of Grade 1 Elementary School Students In Coastal And Urban Areas
}

\author{
Nurasmi $^{1}$, Gusriani ${ }^{2}$, Rahimah $^{3}$ \\ ${ }^{1,2,3}$ Faculty of Health Sciences University of Borneo Tarakan, Indonesia \\ ${ }^{*}$ Corresponding author: \\ Email: yuriasmi22@gmail.com
}

\begin{abstract}
.
Omega 6 is a group of plural unsaturated fatty acids and includes esential fatty acids because is cannot be producet by the body. The unsaturated chain (doubel bond) in the first omega 6 is found in the 6th carbon chain, and therefore it is called omega 6. Student learning achievements both in coastal and urban areas must be the same. The purpose of this study was to determine the effect of consumption of omega 6 on learning achievements of grade 1 elementary school student in coastal and urban areas. This research used analytical research methods with cross sectional design. The population in this study was all grade 1 elementary school student in SDN 032 Amal Lama with 27 students and all grade 1 students in SDN 015 Kampung Enam with 27 students. Samples were taken using the totality population technique with a total of 54 people. The ChiSquare test obtained the value of $P$ in the coastal area was 0.48 , which was $<0.05$, and in the urban area was 0.24 which was $<0.05$, $\mathrm{HO}$ was rejected and $\mathrm{H1}$ was accepted which mean that there was an influence of omega 6 consumption of omega 6 unsaturated fatty acids was not the only major factor in the effect of learning achievement of grade 1 elementary school children in coastal and urban areas. Other factors such as the environment and education of parents also supported in increasing student achievement and in providing information and knowledge to students.
\end{abstract}

Keyword: Learning achievements, Omega 6, Coastal and Urban Elementary Schools.

\section{INTRODUCTION}

Omega 6 is a group of fatty acids plural unsaturated and include acid fatty essential because it not be in production by the body. The chain is not saturated (a double bond) in omega 6, which first contained in the carbon chain to 6 , because that was called omega 6. Omega 6 is the precursor of several important components in the body, such as endocannabionoids, lipoxins, and eicosanoid specific. There are several fatty acids classified as omega 6, namely Linoleic acid, gamma linolenicacid, dihomo-gamma-linoleic acid and arachidonic acid. Omega 6 is found in daily foods, including cereals, soybean oil and nuts. This causes the consumption of omega 6 in the diet in the community tends to be far more than the consumption of omega 3 (Journal of Public Health, 2012). Student achievement in both coastal and urban areas must be the same. Because they have the right to get the same education. Society coast have an opportunity that is equal to the public urban to acquire learning by the students who live in urban significantly higher than students who live in the coastal area. Living environment is one of the factors that influence student achievement. In terms of facilities and infrastructure of urban communities have the means and infrastructure that is already adequate, ranging from the means of education, health and others. So students who live in urban areas will more easily achieve maximum learning achievement (Winda, 2014). Childhood is a critical period, so it is necessary to have a balanced intake of nutrients in children in terms of portions and nutritional content so that children grow smart, healthy, and not easily attacked by disease.

Besides the supporting factors such as genetic and environmental helped influence the behavior of consumption, because children quickly absorb information and tend to mimic the behavior of the people around him, then of the people parents are expected to be able to guide and direct the consumption patterns of children who are good for their health and growth (Sutomo \& Anggraini, 2010). One of the 
efforts to increase the growth and development of children is to consume animal food. Food of animal protein are more qualified because it is easy to use the body and has the amino acid composition is complete. Many vitamins and minerals that are abundant in animal food play a role in normal brain function. Nutrition is very important in the process of growth and development in toddler. One of these nutrients is essential fatty acids needed by the fetus and baby which play a major role in the development of the nervous system and can improve memory skills and learning power (Nurasmi, 2019).Acids fatty omega-6 are sour fat was unsaturated double which is very important for the development and intelligence functions of the brain, reproductive system and metabolism, as well as help maintain healthy skin and hair. The highest concentrations of polyunsaturated fats are found in soybeans, wheat, rice and flax oil. Nutritional status is the state of the body as a result of food consumption and use of nutrients in the body through the process of digestion, absorption, transportation, storage, metabolism, and disposal for maintenance of life, growth and function of organs and for energy production.Based on the background described above, the researchers are interested in doing research on SDN 032 Turkish Amal long and SDN 015 Kampung 6 to see how the effects of the consumption of omega- 6 to the learning outcomes of students.

\section{METHODS}

This study uses analytical research methods that are used to determine the cause and effect between the two variables in an observational manner, where there are differences in relationships, relationships or influences, with a cross sectional design. The population in the study this is a child who is in grade 1 at the School of Basic 015 village 6 with the number of students grade 1 as many as 27 people and Elementary School 032 Amal Lama, with the number of students grade 1 by 27 person.Penelitian ini menggunakan metode penelitian analitik yaitu digunakan untuk mengetahui sebab akibat antara dua variabel secara observasional, dimana bentuk hubungan terdapat perbedaan, hubungan atau pengaruh, dengan rancangan cross sectional. Populasi dalam penelitian ini adalah anak yang berada didalam kelas 1 di Sekolah Dasar 015 Kampung 6 dengan jumlah siswa kelas 1 sebanyak 27 orang dan Sekolah Dasar 032 Pantai Amal Lama, dengan jumlah siswa kelas 1 sebanyak 27 orang.

\section{Analysis}

$\underline{\text { Univariate analysis }}$

analysis by means of frequency distribution.

$$
\mathrm{P}=\frac{f}{N} \times 100 \%
$$

$\mathrm{f}=$ Frequency

$\mathrm{N}=$ Amount

$100 \%=$ Constant

The results of the calculation of the percentage of the effect of consumption of omega 6 on learning outcomes of elementary school children in the coastal areas and non-coastal areas included in the subjective criteria standards, these criteria are:

1. Less $:<68$

2. Enough : 68-79

3. Good : :80-90

4. Very Good : $91-100$ 


\section{Analisis Bivariat}

The bivariate analysis used in this study is the Chi-Square Test to find out the significant relationship between each independent variable with the ordinal periodic dependent variable.

Chi-Square formula:

$\mathrm{X}^{2}=\sum \frac{(f o-f) 2}{f h}$

$$
\mathrm{Df}=(\mathrm{k}-1)(\mathrm{b}-1)
$$

Information :

$\mathrm{X}^{2} \quad$ : Chi Square

fo : Observation Value

fh : Expectation Value

Df : Degree of freedom (b-1) (k-1)

$\mathrm{K} \quad$ : Number of Columns

The interpretation of the calculated $\mathrm{X}$ value compared to the $\mathrm{X}$ table value is as follows:

a. If the $\mathrm{X} 2$ count is greater than the $\mathrm{X} 2$ table then alternative hypotheses can be accepted and reject the null hypothesis.

b. If the X 2 count is smaller than the X 2 table then the alternative hypothesis can be rejected and reject the null hypothesis.

c. Whereas for testing hypotheses based on SPSS, Ho is rejected if $p$ value $<0.05$ and $p$ value $>0.05$ then Ho is accepted.

\section{RESULT}

\section{A. Characteristics of Respondents}

1. Number of Family Members

Table 1. Frequency distribution based on number of families.

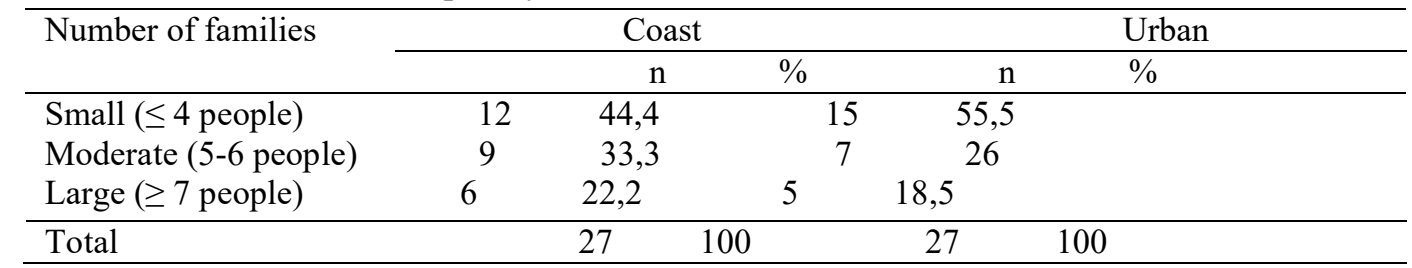

2. Parental Education

Table 2. Frequency distribution based on your education level

\begin{tabular}{|c|c|c|c|c|c|c|}
\hline \multirow{2}{*}{\multicolumn{2}{|c|}{ Education }} & Coast & Coast & \multicolumn{2}{|c|}{ Urban } & \\
\hline & & \multicolumn{2}{|r|}{$\mathrm{n}$} & $\%$ & $\mathrm{n}$ & $\%$ \\
\hline \multicolumn{2}{|c|}{ No / Graduated from elementary school } & 12 & 44,4 & 4 & 14,8 & \\
\hline Junior High School / equivalent & 6 & 22,2 & 1 & 3,7 & & \\
\hline Senior High School / equivalent & 8 & 30 & 15 & 55,5 & & \\
\hline Diploma / College & 1 & 3,7 & 7 & 26 & & \\
\hline Total & 100 & 27 & 100 & & & \\
\hline
\end{tabular}

3. Parents' Work

Table 3. Frequency distribution based on type of work

\begin{tabular}{|c|c|c|c|c|}
\hline \multirow[t]{2}{*}{ Pekerjaan } & \multicolumn{2}{|c|}{ Coast } & \multicolumn{2}{|l|}{ Urban } \\
\hline & $\mathrm{n}$ & $\%$ & $\mathrm{n}$ & $\%$ \\
\hline IRT & 22 & 81,4 & 21 & 77,7 \\
\hline PNS & 1 & 3,7 & 2 & 7,4 \\
\hline Swasta & 3 & 11,1 & 3 & 11,1 \\
\hline Farmers & 1 & 3,7 & 0 & 0 \\
\hline Retired & 0 & 0 & 1 & 3,7 \\
\hline Total & 27 & 100 & 27 & 100 \\
\hline
\end{tabular}


Table 4. Frequency distribution based on parental income

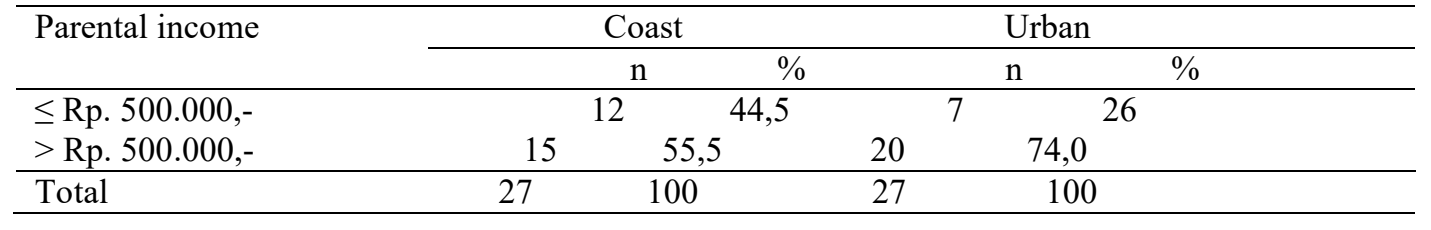

\section{B. Student Characteristics}

Table 5. Frequency distribution based on age and gender characteristics

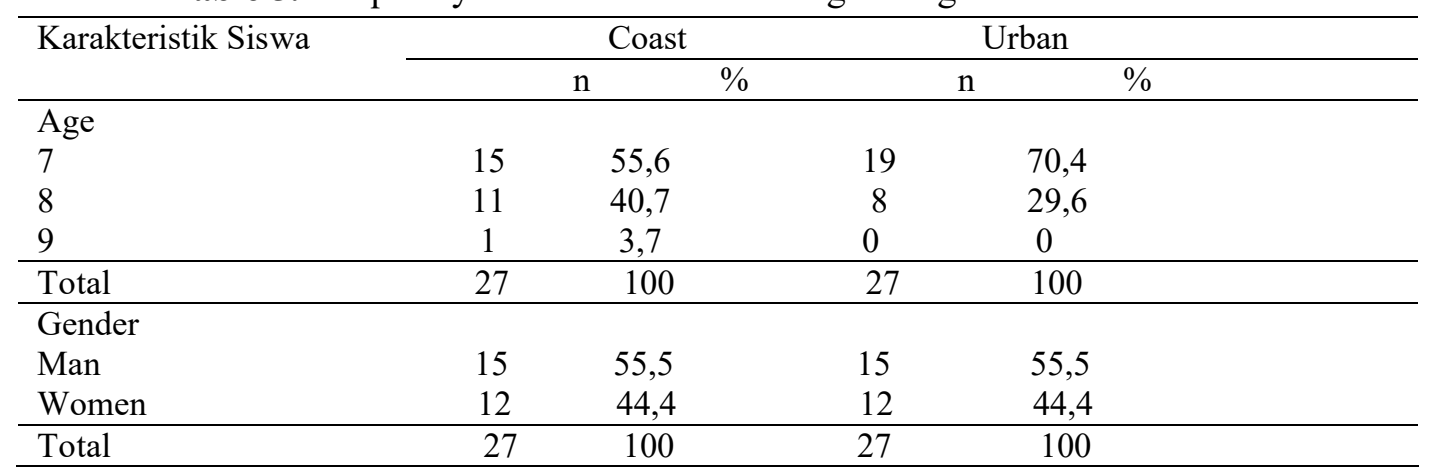

\section{Eating Habits}

Table 6. Frequency distribution based on eating habits

\begin{tabular}{|c|c|c|c|c|c|c|c|c|}
\hline \multirow{2}{*}{\multicolumn{2}{|c|}{ Kebiasaan Makan }} & & & \multicolumn{3}{|c|}{ Coast } & \multicolumn{2}{|c|}{ Urban } \\
\hline & & & & $\mathrm{n}$ & $\%$ & & $\mathrm{n}$ & $\%$ \\
\hline \multicolumn{9}{|c|}{$\begin{array}{l}\text { Eat a full meal } \\
\text { (rice, side dishes, vegetables, fruit) in a day }\end{array}$} \\
\hline a. & 1 times & & & 0 & 0 & & 0 & \\
\hline b. & 2 times & & 2 & 7,4 & & 3 & 11 , & \\
\hline c. & 3 times & & 23 & 85,1 & & 24 & 88,8 & \\
\hline d. & 4 times & & 2 & 7,4 & & 0 & 0 & \\
\hline Total & & 27 & 100 & & 27 & 100 & & \\
\hline a. & Eat fish in a day & & & & & & & \\
\hline b. & 1 times & & 6 & & & 8 & & 9,6 \\
\hline c. & 2 times & & 6 & & & 14 & & 1,8 \\
\hline d. & 3 times & & 15 & & & 5 & & 8,5 \\
\hline e. & 4 times & & 0 & 0 & & 0 & 0 & \\
\hline Total & & 27 & 100 & & 27 & 100 & & \\
\hline
\end{tabular}

1. Consumption of omega 6

Table 7. Frequency distribution based on omega 6 consumption

\begin{tabular}{|c|c|c|c|c|c|}
\hline \multirow[t]{2}{*}{ Omega consumption category 6} & & \multicolumn{2}{|c|}{ Coast } & \multicolumn{2}{|l|}{ Urban } \\
\hline & & $\mathrm{n}$ & $\%$ & $\mathrm{n}$ & $\%$ \\
\hline Sufficient $(\geq 10$ gram $)$ & 15 & 55,5 & 14 & 51,85 & \\
\hline Less than enough $(<10$ gram $)$ & 12 & 44,4 & 13 & 48,14 & \\
\hline Total & 27 & 100 & 27 & 100 & \\
\hline
\end{tabular}

2. Consumption of omega 6

Table 8. Frequency distribution of fish cuttings consumption in a day

\begin{tabular}{|c|c|c|c|c|c|}
\hline \multirow[t]{2}{*}{ Fish Cutlet } & & \multicolumn{2}{|c|}{ Coast } & \multicolumn{2}{|c|}{ Urban } \\
\hline & & $\mathrm{n}$ & $\%$ & $\mathrm{n}$ & $\%$ \\
\hline 1 piece & 5 & 18,5 & 11 & 40,7 & \\
\hline 2 piece & 10 & 37,1 & 14 & 51,8 & \\
\hline 3 piece & 12 & 44,4 & 2 & 7,5 & \\
\hline
\end{tabular}


3.

\begin{tabular}{lllll}
\hline Total & 27 & 100 & 27 & 100
\end{tabular}

3. Non-fish food consumption

Tabel 9. Distribusi frekuensi konsumsi pangan non ikan yang mengandung omega 6

\begin{tabular}{|c|c|c|c|c|c|}
\hline \multirow[t]{2}{*}{ Type of Food Material } & & \multicolumn{2}{|c|}{ Coast } & \multicolumn{2}{|l|}{ Urban } \\
\hline & & $\mathrm{n}$ & $\%$ & $\mathrm{n}$ & $\%$ \\
\hline Eggs & 25 & 92,5 & 22 & 81,4 & \\
\hline Chickens & & 7,4 & & 18,5 & \\
\hline Meat & 0 & 0 & 0 & 0 & \\
\hline Total & 27 & 100 & 27 & 100 & \\
\hline
\end{tabular}

4. Average student learning outcomes

\section{Univariate Analysis}

Table 10. Distribution of student learning achievement frequencies by location

Learning achievement category Coast Urban

\begin{tabular}{|c|c|c|c|c|}
\hline & & $n$ & \multicolumn{2}{|c|}{$\mathrm{n}$} \\
\hline Less $(<68)$ & 0 & 0 & 1 & 3,7 \\
\hline Sufficien (68-79) & 24 & 88,8 & 7 & 25,9 \\
\hline Good $(80-90)$ & 3 & 11,1 & 11 & 40,7 \\
\hline Very Good (91-100) & 0 & 0 & 8 & 29,6 \\
\hline
\end{tabular}

\section{Bivariate Analysis}

Table 11. Results of the chi-square analysis of omega 6 consumption from fish, eggs and chicken foodstuffs on the learning outcomes of grade 1 elementary school children in coastal areas

Chi-Square Test

\begin{tabular}{lrrl}
\hline \multicolumn{1}{c}{ value } & df & $\begin{array}{c}\text { Asymp.Sig. } \\
(2 \text {-sided) }\end{array}$ \\
\hline Pearson Chi-Square & 51.257 & 36 & .048 \\
Likelihood Ratio & 35.621 & 36 & .486 \\
Linear-by-Linear & 3.217 & 1 & .073 \\
Association & & & \\
N ofValid Cases & 27 & & \\
\hline
\end{tabular}

Tabel 12. Results of the chi-square analysis of consumption of omega 6 from fish, eggs and chicken foodstuffs on the learning outcomes of grade 1 elementary school children in urban areas.

Chi-Square Test

\begin{tabular}{lrrr}
\hline & value & df & $\begin{array}{c}\text { Asymp.Sig. } \\
(2 \text {-sided })\end{array}$ \\
\hline Pearson Chi-Square & 69.187 & 48 & .024 \\
Likelihood Ratio & 46.699 & 48 & .485 \\
Linear-by-Linear & 1.700 & 1 & .192 \\
Association & & & \\
N ofValid Cases & & & \\
\hline
\end{tabular}

\section{DISCUSSION}

Based on Table 1 shows that the category of the number of family members in coastal areas with a small category ( $\leq 4$ people) was $44.4 \%$ while in urban areas was $55.5 \%$. Category of number of family members in coastal areas with medium category (5-6 people) by $33.3 \%$ while in urban areas by $26 \%$. The category of the number of family members in the coastal area with a large category ( $\geq 7$ people) was $22.2 \%$, while in the urban area it was $18.5 \%$. The number of family members has a variety of effects, on the one hand the number of family members decreases food security because more family members are considered to be adding to the burden of the 
family in meeting food needs (Pratiwi, 2016). But on the other hand the number of family members will increase food security, because the large number of families allows the number of family members who work, so as to increase food security (Susilowati, 2014). The results of this study are in line with research (Wiwiet Mutiah, 2012) which explains that the number of families will affect the amount of food consumed in the family.

Based on Table 2 it shows that the majority of mothers' education in coastal areas (44.4\%) are not / completed primary school as many as 12 people, while in urban areas most (55.5\%) have high school / equivalent education of 15 people. The results of a study show that a child's learning achievement is very closely related to mother's education. If a mother's education is higher then the child's learning achievement will also increase. This is especially true of girls than boys. Meanwhile, the work of a father does not affect the achievement / learning of a child (Arnold \& Katty 2010). The results of this study are in line with research (Wiwiet Mutiah, 2012) which states that the level of parental education can influence the improvement of children's learning achievement. Educated parents will pay attention and encourage the child's enthusiasm for learning. In addition, to help in the child's educational process, parents need to have good knowledge. The higher the knowledge of parents, the more knowledge parents will give to their children.

Based on Table 3 shows that the occupational categories of mothers of students in coastal areas are generally $(81.4 \%)$ as housewives, while in urban areas the majority $(77.7 \%)$. When mothers do not work and focus on paying attention to their children, children will have good academic achievement and discipline. Mother's attention does not only have an impact on the character or character of the child, one of them is child discipline (Rosdakarya, 2014). The results of this study are in line with research (Wiwiet Mutiah, 2012) which states that work has a relationship with the level of education so that later it will affect its socioeconomic life.

Table 4 shows that the per capita income category of parents per month is mostly (64.8\%) per month of student income per capita per month between $>$ Rp 500,000. per capita per month ( $>$ Rp. 500,000.-) as many as 15 people, while the per capita income of parents per month in coastal areas is mostly $(74.0 \%)$ per capita income per month (> Rp. 500,000.-) as many as 20 people. Family incomes in urban areas are generally higher than in coastal areas, because there are other factors that affect income such as coastal areas where the majority of parents are fisherman workers while in urban areas have more employment opportunities so that income in urban areas is higher than coastal areas, the education of the majority of parents in coastal areas does not complete elementary school, whereas in urban areas the majority have high school / equivalent education so that the level of education also affects one's work and income. (Husaini et al. 2000) said that the socioeconomic status of the family can be seen from the amount of income or expenditure of the family, both food and non-food during the past year. If income is still low then food needs tend to be more dominant than non-food needs. Conversely, if income increases, spending on non-food will be even greater, given the basic food needs have been met. This is in accordance with Engel's Law that the higher the income the smaller the percentage of income spent on food. The results of this study are in line with research (Wiwiet Mutiah, 2012) which states that income is a factor that determines the quantity and quality of food consumed. The higher the income, the greater the opportunity to choose good food. Increased income causes changes in the composition of food. High income tends to be followed by high amount and type of food consumed. The level of income will reflect the ability to buy food.

Based on Table 5 shows that the age category of students is divided into three categories, namely 7, 8 and 9. Most students (63\%) in this study are 7 years old. Students in coastal areas have a percentage (55.6\%) at the age of 7 years, $(47 \%)$ at the age of 8 years and $(3.7 \%)$ at the age of 9 years. Whereas in urban areas the largest percentage was at the age of 7 years $(70.4 \%)$ and the remaining 8 years $(29.6 \%)$. Whereas the sex shows a balanced percentage between the sexes of men and women. The percentage of students in coastal and urban areas is known to have 15 children by $55.5 \%$ students with male gender and 12 children by $44.4 \%$ students with female gender in coastal and urban areas. According to Nurliawati (2003) children are more easily educated at school age compared with children before and after. Therefore, it is very appropriate if elementary students are instilled with basic knowledge of nutrition and good eating habits. The results of this study are in line with 
research (Wiwiet Mutiah, 2012) which states that school-age children receive genuine attention because they are in a period of rapid and active growth. Therefore they need food that meets the nutritional content both in terms of quality and quantity.

Based on Table 6 shows that the categories are based on eating habits. Eating habits are divided into the habit of eating a full meal in a day, and the habit of eating fish. A total of $(87.0 \%)$ students consume a full meal 3 times a day. The category of students in the coastal area $(85.1 \%)$ consumed a full meal 3 times a day, and in urban areas the highest percentage $(88.8 \%)$ students consumed a complete meal 3 times a day. While students who consume fish a day the largest percentage of students (37.0\%) consume fish $2-3$ times a day. (55.5\%) students in coastal areas consume fish 3 times a day while for (51.8\%) students in urban areas consume fish 2 times a day. Eating omega 6 properly can provide benefits for children such as increasing intelligence in children and improving reading skills in children so that it can support children's learning achievement. If you consume less omega 6 will cause metabolic disorders and reduce children's learning intentions so as to make children pay less attention to the results of their learning achievement. Prolonged omega 6 deficiency will be fatal, animal studies show that polyunsaturated fatty acids derived from vegetable oils, especially omega 6 fatty acids are more likely to cause cancer, causing digestive disorders, blocked arteries. Sea fish as one of the catch fisheries products, is a good source of protein, high quality, has a little saturated fat but is rich in a variety of important micro nutrients that humans need (Waisima 2011). The results of this study are in line with research (Wiwiet Mutiah, 2012) which states that the amount of food consumed will affect the coverage of nutrients and nutritional status of individuals. High fish eating culture in Japanese society has proven the occurrence of improving the quality of health and intelligence in children in the country.

Based on Table 7 shows that the majority of students in coastal areas in consuming omega 6 had enough categories ( $\geq 10$ grams) of (55.5\%) as many as 15 children, while students in urban areas in consuming omega 6 majority had sufficient categories ( $\geq 10$ grams) of (51.85\%) as many as 14 children. This shows that the level of omega 6 consumption in coastal and urban areas has quite the same category, so from the study there was no gap between children who consumed omega 6 in coastal and urban areas. Data intake of omega 6 fatty acids is the adequacy value of food intake containing omega 6 fatty acids per day, that is $\geq 10$ grams per day (enough categories) and $<10$ grams per day (less than enough categories) (Wulandari, 2014).

Based on Table 8 shows that the majority of students in coastal areas consume fish in a day is 3 pieces (44.4\%) as many as 12 children, while the majority of students in urban areas consume fish in a day is 2 pieces $(51.8 \%)$ as many as 14 children. This shows that in the coastal areas the majority of fishermen so that in consuming fish food will be easier and more often consume fish compared to urban areas where most children rarely consume fish because it is not so easy to get it. Food consumption is information about the type and amount of food (consumed) a person or group of people at a certain time, so that the assessment of food consumption can be based on the amount and type of food consumed (Hardinsyah \& Briawan 1994).

Based on Table 9 shows that categories based on the type of non-fish food consumed include eggs that have a large enough percentage (87.0\%) in coastal and urban areas, while chicken food consumption has a percentage (12.9\%). This shows that non-fish food items such as eggs, chicken and meat also contain omega 6 which influences children's intelligence which can improve children's learning achievement, so it can be concluded that foodstuffs such as eggs, chicken and meat have an influence on omega 6 consumption on achievement results learning grade 1 elementary school children in coastal and urban areas. Animal food sources are a source of protein which is rich in essential amino acids, can not be synthesized in the body is very necessary for the growth and development of the organs of the toddler's body so it must be in food. Animal food sources consist of eggs, poultry meat, beef and fish (Uripi, 2004). The results of this study are in line with (Wiwiet Mutiah, 2012) which states that animal food is beneficial in supporting the physical growth of children and also supports the cognitive development of children and animal food ingredients such as eggs which are consumed the most in children. 
Based on Table 10 shows that categories based on children's learning outcomes can be known the average student learning outcomes in coastal areas with very good grades (91-100) are (0\%) and urban areas with very good grades (91-100) as many as 8 students is $(28.6 \%)$. Whereas student learning outcomes in coastal areas with good grades (80-90) as many as 3 students were (11.1\%) and urban areas with good grades (80-90) of 11 students (40.7\%). Student learning outcomes in coastal areas with sufficient grades (68-79) as many as 24 students are $(88.8 \%)$ and in urban areas with sufficient grades of 7 students is $(25.9 \%)$. Then student learning outcomes in coastal areas with less grades $(<68)$ are $(0 \%)$ while in urban areas with less grades $(<68)$ as many as 1 student is $(3.7 \%)$. This shows that the majority of students in urban areas have good categories compared to coastal areas which the majority have enough categories. Slameto (2010: 56) states that, "the factors that influence student learning outcomes are classified into two groups, namely external factors and internal factors. External factors are factors that come from outside the individual can come from family, school, society for example family harmony, parental education, parental occupation, and parental income. Internal factors are factors that come from within individual students, both physical and spiritual, for example attitudes, intelligence, and so on (Lisda Hayati, 2015). The results of this study are in line with research (Wiwiet Mutiah, 2012) which states that significant differences are thought to occur due to several aspects, some of which are caused by several regions being observed. Coastal areas are areas that are farther away from the center of regional government compared to urban areas. In addition, differences in socioeconomic characteristics of parents also affect student learning achievement. Urban areas are areas close to the center of government, the average work of parents of students is also more diverse ranging from civil servants to entrepreneurs. Education in urban areas is also better thancoastal areas, which on average only graduate from elementary school.

Based on Table 11 shows that from the learning outcomes and consumption of fish, eggs, chicken and meat containing omega 6 in the coastal areas, the Asymp.Sig (2-sided) value is smaller than the P value $(0.48$ $<0.05)$, thus it can be interpreted that "There is an influence between consumption of omega 6 on the learning outcomes of primary school children grade 1 in the coastal areas". This shows that omega 6 food also plays a role in the level of children's intelligence so that it can help improve learning outcomes in children. There are other factors that influence children's learning outcomes, such as the results of research obtained by the level of education of parents in the area exactly are elementary school graduates and the average value of learning outcomes of primary school children grade 1 in coastal areas is 75 . This shows that the level of parental education can also be influential in efforts to improve children's learning achievement. In addition, to assist in the process of children's education, parents should enhance their knowledge, the higher the knowledge of parents, the more knowledge parents will give to their children (Agustina, 2003). The results of this study are in line with research (Wiwiet Mutiah, 2012) which states that there is a real relationship between nutritional status, parental education and fish consumption on student achievement. the more parents' knowledge is given to their children (Agustina, 2003). The results of this study are in line with research (Wiwiet Mutiah, 2012) which states that there is a real relationship between nutritional status, parental education and fish consumption on student achievement. the more parents' knowledge is given to their children (Agustina, 2003). The results of this study are in line with research (Wiwiet Mutiah, 2012) which states that there is a real relationship between nutritional status, parental education and fish consumption on student achievement.

Based on Table 12 shows that from the results of learning and consumption of fish, eggs, chicken and meat in urban areas, the Asymp.Sig value (2-sided) is smaller than the P value $(0.24<0.05)$, thus it can be interpreted that "There is an influence between consumption of fish, eggs, chicken and meat containing omega 6 to the learning outcomes of grade 1 elementary school children in urban areas". This shows that foodstuffs such as eggs, chicken and meat contain omega 6 also plays an important role in the level of intelligence of children so as to improve learning outcomes in children. There are other factors that affect children's learning outcomes such as the results of research obtained by the level of education of parents in urban areas are high school graduates and the average value of learning outcomes of primary school children grade 1 in urban areas is 83 . This shows 
that the level of education of parents can also influential in efforts to improve children's learning achievement. In addition, to assist in the process of children's education, parents should enhance their knowledge, the higher the knowledge of parents, the more knowledge parents will give to their children (Agustina, 2003).

\section{CONCLUSION}

There is a relationship of omega 6 consumption with the learning achievement of grade 1 elementary school students in coastal areas, where from the analysis results obtained Asymp. Sig value is smaller than the $\mathrm{P}$ value $(0.48<0.05)$ and there is a relationship between omega 6 consumption with achievement class 1 elementary school student learning in urban areas, where from the analysis results obtained Asymp. Sig value is smaller than the value of $\mathrm{P}$ value $(0.24<0.05)$.

\section{ACKNOWLEDGMENT}

Thank you to friends who have helped in research ii as well as students on behalf of Eni who have helped in data collection.

\section{REFERENCES}

[1] Agustina H. 2003. Alokasi Waktu Anak Untuk leisure dan Hubungannya dengan Prestasi Belajar Siswa SD di Kota Medan [skripsi]. Bogor: Fakultas Pertanian, Institut Pertanian Bogor.

[2] Ariani, Dhorothea Wahyu. 2009. Management Operasi Jasa. Penerbit Graha Ilmu. Yogyakarta

[3] Arikunto, 2002. Prosedur Penelitian Suatu Pendekatan Praktek Yogyakarta : Rineka Cipta

[4] Arikunto, S. 2012. Prosedur Penelitian Suatu Pendekatan Praktek. Rinka Cipta. Yogyakarta

[5] Asmin RM. 2000. Keragaan Prestasi Belajar Anak Sekolah Dasar Penerima PMT-AS di Daerah Pegunungan dan Pantai Propinsi Nusa Tenggara timur [skripsi]. Bogor: Fakultas Pertanian Institut Pertanian Bogor.

[6] Atkinson et. al., 2000. Management Accounting. Second Edition. Prentice Hall

[7] Audrey N, Maretzki, Erward E. 2003. Applying a NutriBusiness Approach to Increase Animal Source Food Consumption in Local Communities. Jounral of Nutrition. 133(11 Suppl 2):4031S-4035S

[8] Bardosono S. 2011. Anak sekolah di Indonesia kurang gizi. http://www.republika.co.id/berita/gaya-hidup/infosehat/11/09/18/lrpl3l-anak-sekolah-diindonesia-kurang-gizi. [18 September 2011]

[9] Burdge G. 2004. Alpha-lonolenic acid metabolism in men and women: Nutritional and Biological Implications. Current Opinion in Clinical Nutrition and Metabolic Care 7(2):137-144.

[10] Choo PS, Williams MJ. Fisheries Production in Asia : Its Role in Food Security and Nutrition. NAGA, WorldFish Center Quarterly 2003 Vol. 26 No. 2

[11] Devi N. 2012. Gizi Anak Sekolah. Jakarta: PT Kompas Media Nusantara

[12] Dharma, Kusuma Kalena. 2011. Metodologi Penelitian Keperawatan : Panduan Melaksanakan dan Menerapkan Hasil Penelitian, Jakarta, Trans InfoMedia

[13] Diana, Fivi Melva, 2012 Omega 6. Jurnal Kesehatan Masyarakat. Vol 7 No. 1, September 2012. Diambil dari http://jurnal.fkm.unand.ac.id//article/view/98/104. ( 11 Maret 2013)

[14] Fernandez et al. 1999. Fish consumption and cancer risk. American Journal Clinical of Nutrition. 70:85-90

[15] Hawadi RA. 2001. Psikologi Perkembangan Anak: Mengenal Sifat, Bakat, dan Kemampuan Anak. Jakarta: PT Gramedia Widiasarana Indonesia

[16] Hardinsyah dan Briawan D. 1994. Penilaian dan Perencanaan Konsumsi Pangan. Jurusan Gizi Masyarakat dan Sumber Daya Keluarga, Fakultas Pertanian, Institut Pertanian Bogor. Bogor.

[17] Hardinsyah. Martianto D. 1992. Gizi Terapan. Bogor: Departemen Pendidikan dan Kebudayaan, Direktorat Jenderal Pendidikan Tinggi, Pusat Antar Universitas Pangan dan Gizi, Institut Pertanian Bogor.

[18] Hurlock, 1999. Psikologi Perkembangan : Suatu Pendkatan Sepanjang Rentang Kehidupan. Edisi kelima (Terjemahan oleh Istiwidayanti). Jakatra: Erlangga.

[19] Husnaini YK, Widodo Y. Triwinarto A. Salimar 2000. Perubahan Pola Konsumsi Pangan Keluarga pada sebelum dan sewaktu krisis Ekonomi. Penelitan gizi dan makanan 23: 8-17

[20] Nia K, Pontoh, Iwan Kustiwan. Pengantar Perencanaan Perkotaan. Bandung: Ganesa; 2008 
[21] Notoatmodjo. 2010. Metodologi Penelitian Kesehatan. Jakarta : PT. Rikena Cipta

[22] Notoadmodjo, Soekidjo. 2012. Promosi Kesehatan dan Prilaku Kesehatan. Jakarta : Rikena Cipta.

[23] Nurasmi, N., \& Susanti, S. (2019). Analisis Potensi Asam Lemak Omega 3, Omega 6, Dan Omega 9 Dari Rumput Laut (Kappaphycus Alvarezii) Pada Peningkatan Nutrisi Balita. Jurnal Borneo Saintek, 2(1), 33-36.

[24] Nurliawati L. 2003. Kebiasaan Jajan dan Preferensi Anak Sekolah Dasar Terhadap Makanan Jajanan dengan Pewarna Sintetik (Skrisi). Bogor. Fakultas Pertanian, Institut Pertanian Bogor.

[25] Ramon et al. 2009. Fish consumption during pregnancy, prenatal mercury exposure, and anthropometric measures at birth in a prospective motherinfant cohort study in Spain. American Journal of Nutrition. 90:1047-55

[26] Rokhim Dahuri MS, dkk. Sumber Daya Wilayah Pesisir dan Lautan Secara Teradu. Jakarta: Balai Pustaka, 2013.

[27] Saryono, MD Anggraeni. 2013. Metodologi Penelitian Kuantitatif Dalam Bidang Kesehatan. Yogyakarta : Nuha Medika.

[28] Semba et al. 2008. Effect of parental formal education on risk of child stunting in Indonesia and Bangladesh: a cross-sectional study. The Lancet: Vol 371, Issue 9609, 322 - 328.

[29] Sugiyono, 2007. Metodologi Penelitian Bisnis, PT. Gramedia, Jakarta.

[30] Supariasa IDN, Bakri B, Fajar I. 2002. Penilaian Status Gizi. Jakarta: Buku Kedokteran EGC.

[31] Sutomo, B dan Anggraini, DY. 2010. Menu Seha Alami Untuk Balita \& Balita. Jakarta: PT, Agromedia Pustaka

[32] Sutomo. 2007. Prestasi Anak yang Menderita GAKI dan Tidak Menderita GAKI di daerah Endemik Barat di SD Negeri 1 dan 2 Tribudaya Kecamatan Amonggedo, Kabupaten Konawe, Propinsi Sulawesi Tenggara [Skripsi]. Bogor: Fakultas Ekologi Manusia, Institut Pertanian Bogor.

[33] Waisima. 2011. Pengaruh Ibu pada Perilaku Makan Ikan Laut Siswa Sekolah Dasar di Kabupaten Jepara dan Kabupaten Grobogan, Jawa Tengah [Disertasi]. Bogor : Sekolah Pascasarjana, Institut Pertanian Bogor.

[34] Winda P, Uswatun Hasanah Isna, 2014. Pengaruh Lingkungan Tempat Tinggal dan Fasilitas Belajar Terhadap Prestasi Belajar Siswa Kelas IV MI Muhammadiyah Ngasem Tahun Pelajaran 2013/2014. Jurnal Universitas Muhammadiyah Surakarta. 